\title{
PROGRAMOWANIE I WDRAŻANIE FUNDUSZY STRUKTURALNYCH I FUNDUSZU SPÓJNOŚCI W POLSCE, REPUBLICE CZESKIEJ I NA WĘGRZECH - EFEKTY I PERSPEKTYWY
}

\section{WPROWADZENIE}

Głównym celem polityki regionalnej, w dążeniu do osiagnięcia spójności gospodarczej, społecznej i terytorialnej Unii Europejskiej jest zmniejszanie dysproporcji w poziomach rozwoju regionów oraz zacofania regionów najmniej uprzywilejowanych ${ }^{1}$. Polska, Republika Czeska (RC) i Węgry, przystępując do UE w 2004 r., obarczone były luką rozwojową w stosunku do państw UE-15 i narastającymi zróżnicowaniami wewnętrznymi ${ }^{2}$. Polityka regionalna (spójności) i jej fundusze stały się dominującym źródłem inwestycji publicznych ukierunkowanych na rozwój społeczno-gospodarczy tych państw i ich regionów. Jednak koncepcja polityki regionalnej, w tym jej cele, instrumenty oraz system implementacji ewaluują wraz z kolejnymi rozszerzeniami i wyzwaniami w Unii i w jej otoczeniu. Odchodzi ona od paradygmatu polityki wyrównawczej, która koncentruje się na rozwoju infrastruktury technicznej i kapitału rzeczowego, na rzecz polityki prokonkurencyjnej, inwestycyjnej i innowacyjnej ${ }^{3}$. Ponieważ polityka regionalna stanowi dziedzinę kompetencji dzielonej, promuje między innymi zasady pomocniczości, partnerstwa czy podziału zarządzania. Włączanie regionów w proces decyzyjny wynika zarówno z postępującej decentralizacji, jak i potrzeby podniesienia efektywności działań wspólnotowych dzięki lepszemu zorientowaniu w rzeczywistej sytuacji regionów ${ }^{4}$. Jej priorytety są jednak ustalane na poziomie ponadnarodowym, podobnie jak cele (zwłaszcza tematyczne), zasady i ramy finansowania. Państwa członkowskie tworzą system zarządzania i kontroli środków unijnych, opierając się na własnych instytucjach, ale pozostających pod nadzorem Komisji Europejskiej (KE) ${ }^{5}$.

Celem artykułu jest ukazanie podobieństw i różnic w priorytetach, podziale funduszy i instytucjonalnych systemach wdrażania funduszy strukturalnych

\footnotetext{
${ }^{1}$ Artykuł 174 TFUE Dz. Urz. UE C 326, 26.10.2012: 127.

${ }^{2}$ Domański, Guzik, Micek (2003): 125-142; Bachtler, Downes, Gorzelak (2000).

${ }^{3}$ Klimowicz (2014): 204; Dorożyński (2012).

${ }^{4}$ Pietrzyk (2001): 199.

${ }^{5}$ Świstak (2018): 176-191.
} 
i Funduszu Spójności w Polsce, Republice Czeskiej i na Węgrzech w kolejnych okresach programowania, co przyczyni się do oceny efektów i skuteczności implementacji funduszy polityki spójności w niwelowaniu luki rozwojowej tych państw i zróżnicowań między regionami. Analiza dokumentów programowych wdrażanych przez Polskę, Czechy i Węgry w latach 2004-2006, 2007-2013 i 2014-2020 oraz raportu: „EU budget 2008. Financial Report za lata 20002008" umożliwiła porównanie alokacji funduszy UE na poszczególne kraje, lata, programy i priorytetowe dziedziny wsparcia, a także zmiany w podziale kompetencji między instytucje pełniace funkcje zarządzania. Analiza ministerialnych sprawozdań i niezależnych badań na temat wykorzystania funduszy w regionach wskazuje na zróżnicowany udział regionów w funduszach polityki spójności. Badania literaturowe na temat konwergencji w nowych państwach członkowskich, raporty kohezyjne Komisji Europejskiej oraz dane ministerstw pełniących funkcje instytucji zarządzających ukazywały niekiedy rozbieżne oceny efektów polityki spójności w regionach. Na podstawie danych statystycznych Eurostatu i GUS-u zbadano zmiany w zaludnieniu, stopie bezrobocia, PKB per capita $\mathrm{w}$ relacji do średniej UE oraz strukturze WDB zachodzące między rokiem 2004 i ostatnim rokiem odnotowanym w regionach NUTS 2 tych państw. W celu oceny dysproporcji regionalnych zbadano stosunek PKB per capita dla drugiego i ostatniego regionu oraz współczynnik zmienności regionalnego $\mathrm{PKB}$ per capita w 2004 i 2017 r. Przedmiotem porównań regionalnych jest poziom NUTS 2, który odgrywa zasadniczą rolę w planowaniu i wydatkowaniu środków UE. W momencie akcesji odpowiadał on w Polsce 16 samorządowym województwom (po rewizji w 2016 r. 17 NUTS 2), w Czechach zaś i na Węgrzech powołano regiony statystyczne nieposiadające legitymacji politycznej (odpowiednio 8 i 7 , obecnie po 8$)^{6}$. Samorządowe czeskie kraje (14) reprezentuja poziom NUTS 3, podobnie jak węgierskie komitaty, będące jednostkami administracji rządowej.

\section{PORÓWNANIE SYSTEMÓW IMPLEMENTACJI FUNDUSZY STRUKTURALNYCH I FUNDUSZU SPÓJNOŚCI W TRZECH OKRESACH PROGRAMOWANIA - CZECHY, POLSKA I WĘGRY}

W budżecie funduszy strukturalnych i Funduszu Spójności na lata 20002006 dla 10 nowych państw członkowskich (NPC) przyznano 21,7 mld euro, co stanowiło 10-krotnie mniej środków aniżeli dla UE-157. Tymczasem większość NPC została w całości objęta Celem 1 polityki spójności, jako obszary słabiej rozwinięte, o PKB per capita poniżej 75\% średniej unijnej w regionach NUTS 2 (w tym 16 województw w Polsce i 7 regionów na Węgrzech). W Czechach 7 spośród 8 regionów NUTS 2 zakwalifikowano do Celu 1, region stołeczny Pragi zaś - do Celu 2 (wsparcia ekonomicznych i społecznych zmian strukturalnych)

\footnotetext{
${ }^{6}$ Zob. $<$ https://stat.gov.pl/statystyka-regionalna/jednostki-terytorialne/klasyfikacja-nuts/liczbajednostek-nuts-w-panstwach-czlonkowskich-unii-europejskiej/>.

${ }^{7}$ Zob. <https://ec.europa.eu/regional_policy/sources/docgener/panorama/pdf/mag26/mag26_ pl.pdf>.
} 
oraz Celu 3 (pomocy horyzontalnej na rzecz zatrudnienia i edukacji). Rozdysponowanie funduszy strukturalnych na cele i programy operacyjne realizowane w tych państwach ukazano w tabeli 1. Zgodnie z Podstawami Wsparcia Wspólnoty alokacja funduszy strukturalnych w latach 2004-2006 w Celu 1 wyniosła w Republice Czeskiej 1454,3 mln euro, na Węgrzech - 1995,7 mln euro i w Polsce $-8275,8$ mln euro ${ }^{8}$. Regiony Celu 1 uzyskały wsparcie ze wszystkich funduszy strukturalnych: Europejskiego Funduszu Rozwoju Regionalnego (EFRR), Europejskiego Funduszu Społecznego (EFS), Sekcji Orientacji - Europejskiego Funduszu Orientacji i Gwarancji Rolnej (EFOGR) oraz Finansowego Instrumentu Wsparcia Rybołówstwa (FIWR), przy czym największe - z EFRR. Ich udział w budżecie UE dla Celu 1 wyniósł w badanym okresie zaledwie 5\% dla Polski, 1,6\% - Węgier i 0,7\% - Czech ${ }^{9}$. Udział regionu Pragi w finansowaniu Celu 2 i 3 był również marginalny (łącznie 0,3\%). Spośród czterech inicjatyw wspólnoty NPC wdrażały jedynie dwie: Interreg III na rzecz współpracy transgranicznej, transnarodowej i międzyregionalnej z państwami UE (dofinansowanej z EFRR) oraz Equal - wyrównywanie szans na rynku pracy osób zagrożonych bezrobociem (z EFS).

Nowe państwa członkowskie stały się również beneficjentami Funduszu Spójności, ponieważ spełniały kryterium dochodu narodowego brutto (DNB) poniżej 90\% średniej UE. Jego wkład w finansowanie dużych projektów inwestycyjnych w infrastrukturze transportowej i ochronie środowiska wyniósł w Polsce 4178,8 mln euro, na Węgrzech 1112,7 mln euro, w Czechach zaś 945,3 mln euro, co stanowiło $1 / 3$ przyznanej im pomocy strukturalnej UE na lata 20042006. Odrębne zasady jego wsparcia zostały ujęte w Strategii Wdrażania Funduszu Spójności. Programowanie funduszy strukturalnych w regionach Celu 1 obejmowało Podstawy Wsparcia Wspólnoty (PWW), odzwierciedlające założenia Narodowego Planu Rozwoju na lata 2004-2006, programy operacyjne i ich uzupełnienia. Jak wynika z tabeli 1 , dominowały programy sektorowe, a największe środki skierowano na rozwój zasobów ludzkich, wsparcie konkurencyjności gospodarek i przedsiębiorstw, infrastruktury transportowej i ochrony środowiska. W Polsce alokacja Sekcji Orientacji-EFOGR na rolnictwo i rozwój obszarów wiejskich nieznacznie przewyższała środki EFRR na SPO Transport. Jednakże po uwzględnieniu wsparcia z Funduszu Spójności na pierwsze miejsce wysunęły się sektory transportu i ochrony środowiska. Państwa te wdrażały wspólny dla wszystkich regionów program rozwoju regionalnego współfinansowany z EFRR i EFS, przeznaczając na niego od 18\% (Węgry) do 1/3 (RC i Polska) alokacji na PWW. W przypadku regionu Pragi zastosowano uproszczona procedurę Jednolitego Dokumentu Programowego dla Celu 2 i Celu 3. Niemniej programowanie i wydatkowanie funduszy UE w krótkim czasie i na różnych zasadach w poszczególnych celach było w Czechach bardziej skomplikowane. Instytucją zarządzającą (IZ) JDP Celu 2 było Ministerstwo Rozwoju Regionalnego, które przekazało pewne funkcje wyboru i wdrażania projektów

${ }^{8}$ Ministerstvo Pro Mistni Rozvoj (2003): 117; National Development Office (2003): 125; Ministerstwo Gospodarki, Pracy i Polityki Społecznej (2003): 99 i 136-137.

${ }^{9}$ Zob. <https://ec.europa.eu/info/publications/financial-report-2008_en>. 


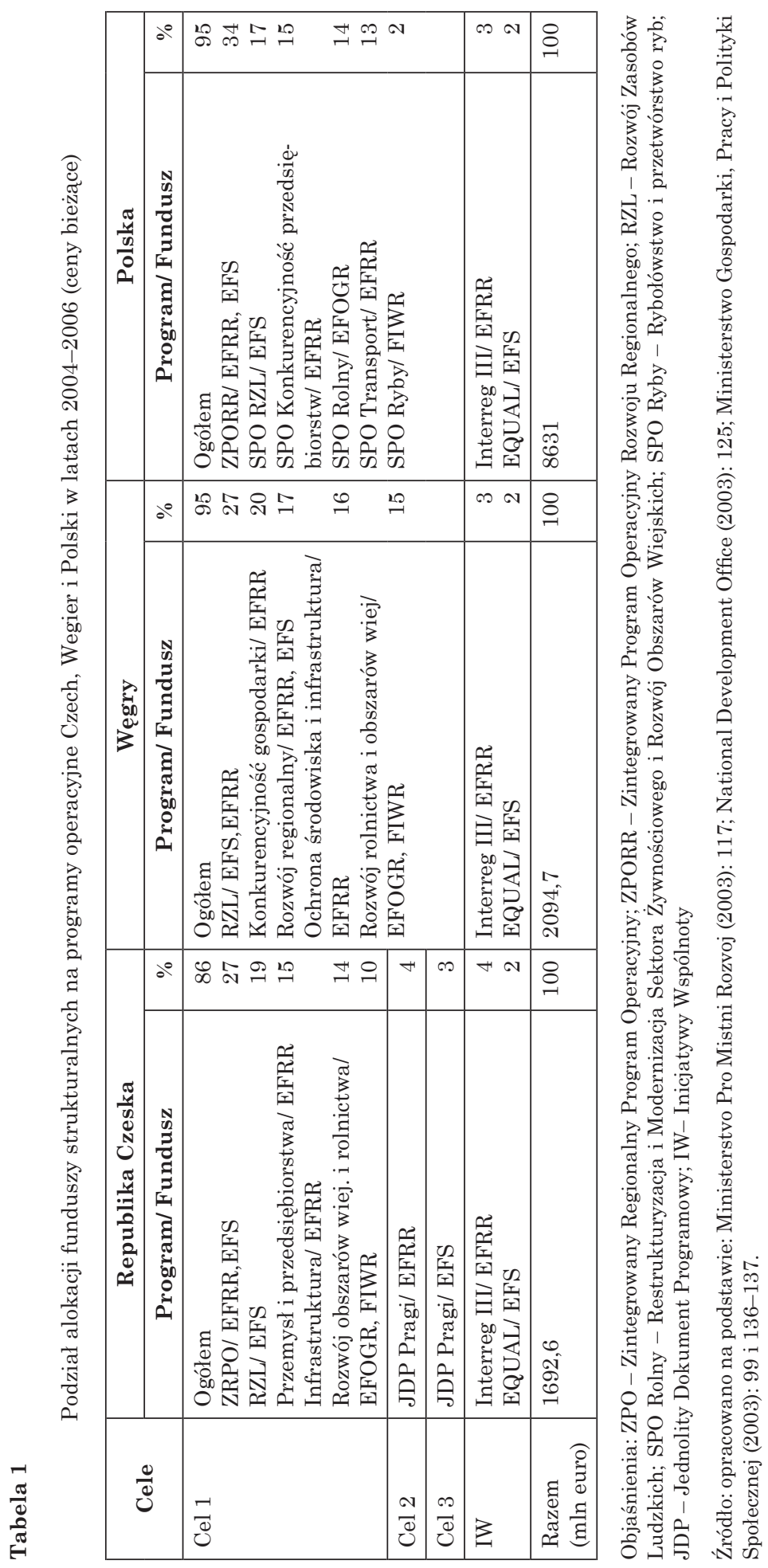


radzie regionu Pragi. Natomiast IZ JDP Celu 3 oraz programu Rozwój Zasobów Ludzkich było Ministerstwo Pracy i Spraw Socjalnych. Za zarządzanie PWW, w tym zintegrowanym programem regionalnym, Inicjatywami Wspólnoty oraz Strategią Wdrażania Funduszu Spójności odpowiadało ministerstwa ds. rozwoju regionalnego w RC i Polsce oraz Biuro Rozwoju Narodowego na Węgrzech. IZ w pozostałych programach były właściwe resorty. Udział władz regionalnych został ograniczony do wyboru projektów (np. samorządy województw w ZPORR), jednakże pod nadzorem władz centralnych. Skrócony okres programowania i skromny udział nowych państw w budżecie polityki spójności uzasadniały mniejszą liczbę programów i uproszczenie systemu implementacji, w tym skoncentrowanie funkcji zarządzania $\mathrm{w}$ ministerstwie ds. rozwoju regionalnego czy powołanie instytucji płatniczej dla funduszy strukturalnych i Funduszu Spójności w departamentach ministerstw finansów $)^{10}$.

Uczestnictwo w pełnym okresie programowania polityki spójności UE w latach 2007-2013 i przewaga regionów o niższym poziomie rozwoju skutkowały zwiększeniem alokacji dla tych państw. W efekcie stały się one głównymi beneficjentami funduszy strukturalnych (EFRR, EFS) i Funduszu Spójności, na czele z Polska - 19\%, dalej Czechy - 7,7\% i Węgry 7,3\%. Wszystkie polskie województwa, 7 czeskich i 6 węgierskich regionów NUTS 2 zostały zaliczone do celu Konwergencja, regiony Pragi zaś oraz Środkowe Węry (z Budapesztem) zakwalifikowały się do celu Konkurencyjność regionalna i zatrudnienie (KRZ) (na zasadach phasing-in). Zniesiono Inicjatywy Wspólnoty, jedynie Inicjatywa Interreg ,awansowała” do nowego celu Europejska Współpraca Terytorialna (EWT) finansowanego z EFRR. Państwa członkowskie wdrażały fundusze strukturalne i Fundusz Spójności na podstawie Narodowych Strategicznych Ram Odniesienia i programów operacyjnych. W Polsce operacjonalizację Narodowej Strategii Spójności stanowiło 5 programów krajowych i 16 regionalnych, w celu EWT - 7 programów współpracy transgranicznej i 2 programy współpracy transnarodowej oraz 2 programy Europejskiego Instrumentu Sasiedztwa i Partnerstwa ${ }^{11}$. Na Wegrzech i w RC unijne fundusze zaprogramowano na wszystkie cele polityki spójności. System operacyjny Nowego Planu Rozwoju Węgier obejmował 8 programów krajowych, 6 programów regionalnych (dla Konwergencji) i program dla Środkowych Węgier (KRZ), a ponadto 10 programów EWT ${ }^{12}$. W Czechach wdrażano 8 krajowych programów tematycznych, 7 programów regionalnych dla celu Konwergencja i 2 programy dla regionu Pragi (KRZ), a także 7 programów EWT. Część programów krajowych wdrażano w tych państwach zarówno w celu Konwergencja, jak i KRZ (por. tabela 2). W podziale funduszy UE na lata 2007-2013 dominuja sektory transportu, ochrony środowiska i energetyki (ponad 40\% unijnych środków, w tym cała alokacja Funduszu Spójności), podczas gdy na badania i innowacyjne przedsiębiorstwa przeznaczono niespełna $20 \%$ dofinansowania w RC oraz ok. $12 \%$ w Polsce i na Węgrzech. Na programy regionalne

\footnotetext{
10 Szafran (2016): 100.

11 Ministerstwo Rozwoju Regionalnego (2007): 115-117.

12 The Government of the Republic of Hungary (2007): 132, 135-136.
} 
na Węgrzech i Czechach (łącznie w celach Konwergencja i KRZ) przeznaczono ok. ${ }^{1 / 5}$ alokacji (przy czym dodatkowym wsparciem w tych drugich był Zintegrowany program operacyjny), w Polsce zaś $1 / 4$ alokacji (28\% łącznie z ponadregionalnym programem Rozwój Polski Wschodniej).

System zarządzania był na Węgrzech skoncentrowany w Agencji Rozwoju Narodowego (ARN), której departamenty pełniły funkcje instytucji zarządzających zarówno programów krajowych, jak i regionalnych. Kompetencje rad i agencji rozwoju regionalnego powołanych w 1996 r., aby wzmocnić wielopoziomowe zarządzanie, ograniczono do opiniodawczo-doradczych, następnie w 2012 r. zlikwidowano rady, a agencje podporządkowano ministerstwu rozwoju i ARN ${ }^{13}$. W Polsce za koordynację wdrażania unijnych funduszy i zarządzanie programami krajowymi odpowiadało Ministerstwo Rozwoju Regionalnego. W Czechach koordynowało ono wdrażanie EFRR i FS, a Ministerstwo Pracy i Spraw Socjalnych - EFS, natomiast funkcje IZ programami krajowymi pełniły właściwe resorty. Ponadto powołano Instytucje Pośredniczące oraz Audytowe i Certyfikujace (departamenty w Ministerstwie Finansów). W Polsce i RC zarządzanie programami regionalnymi leżało $\mathrm{w}$ gestii władz regionalnych: samorządów województw, rad regionalnych i Urzędu Miasta Pragi).

W latach 2014-2020 Czechy i Węgry odnotowały spadek udziału w budżecie polityki spójności (do ok. 6\%), natomiast Polska pozostała jej głównym beneficjentem (22\%). Kontynuowany jest cel EWT (finansowany z EFRR), a w nowym celu: „Inwestycje na rzecz wzrostu gospodarczego i zatrudnienia” (wspartym z EFRR, EFS i FS) wyodrębniono trzy kategorie regionów. Do lepiej rozwiniętych regionów (o PKB per capita powyżej 90\% średniej UE) należą jedynie stołeczne regiony. Nie występuje kategoria przejściowa, a pozostałe regiony NUTS 2 pozostają w kategorii słabiej rozwiniętych (poniżej 75\% średniej UE). Wydatkowanie funduszy strukturalnych i Funduszu Spójności następuje zgodnie z Umową Partnerstwa i programami operacyjnymi, które w większości są kontynuacją programów z poprzedniego okresu. Czechy i Węgry połączyły priorytetowe dziedziny wsparcia w mniejszą liczbę programów krajowych (po 5) oraz realizuja jeden wspólny program dla regionów słabiej rozwiniętych i jeden dla regionu lepiej rozwiniętego. W Polsce zamiast PO Innowacyjna Gospodarka realizowane sa dwa programy: Innowacyjny Rozwój i Polska Cyfrowa, pozostałe zaś programy krajowe i 16 programów regionalnych (przy zakwalifikowaniu Mazowsza do regionu lepiej rozwiniętego) sa nieco zmodyfikowane i kontynuowane. Istotna zmiana jest skoncentrowanie funduszy na 11 celach tematycznych (np. EFRR cele 1-4 i inne, EFS cele 8-11, FS cele 4-7 i 11), co znajduje wyraz w priorytetach wszystkich programów. Wzrosły nakłady na innowacyjność przedsiębiorstw oraz ochronę środowiska, gospodarkę niskoemisyjną i dostosowanie do zmian klimatu (ok. 1/3 środków na Węgrzech, niemal 26\% w Czechach i 23\% w Polsce). Największe nakłady $\mathrm{w}$ tych ostatnich kierowane są nadal na infrastrukturę transportowa (odpowiednio $26 \%$ i $29 \%$ ). Podział odpowiedzialności w systemie instytucjonalnym ukazuje centralizację programowania i wdrażania funduszy UE, zwłaszcza

13 Pálmai (2013): 460-465. 


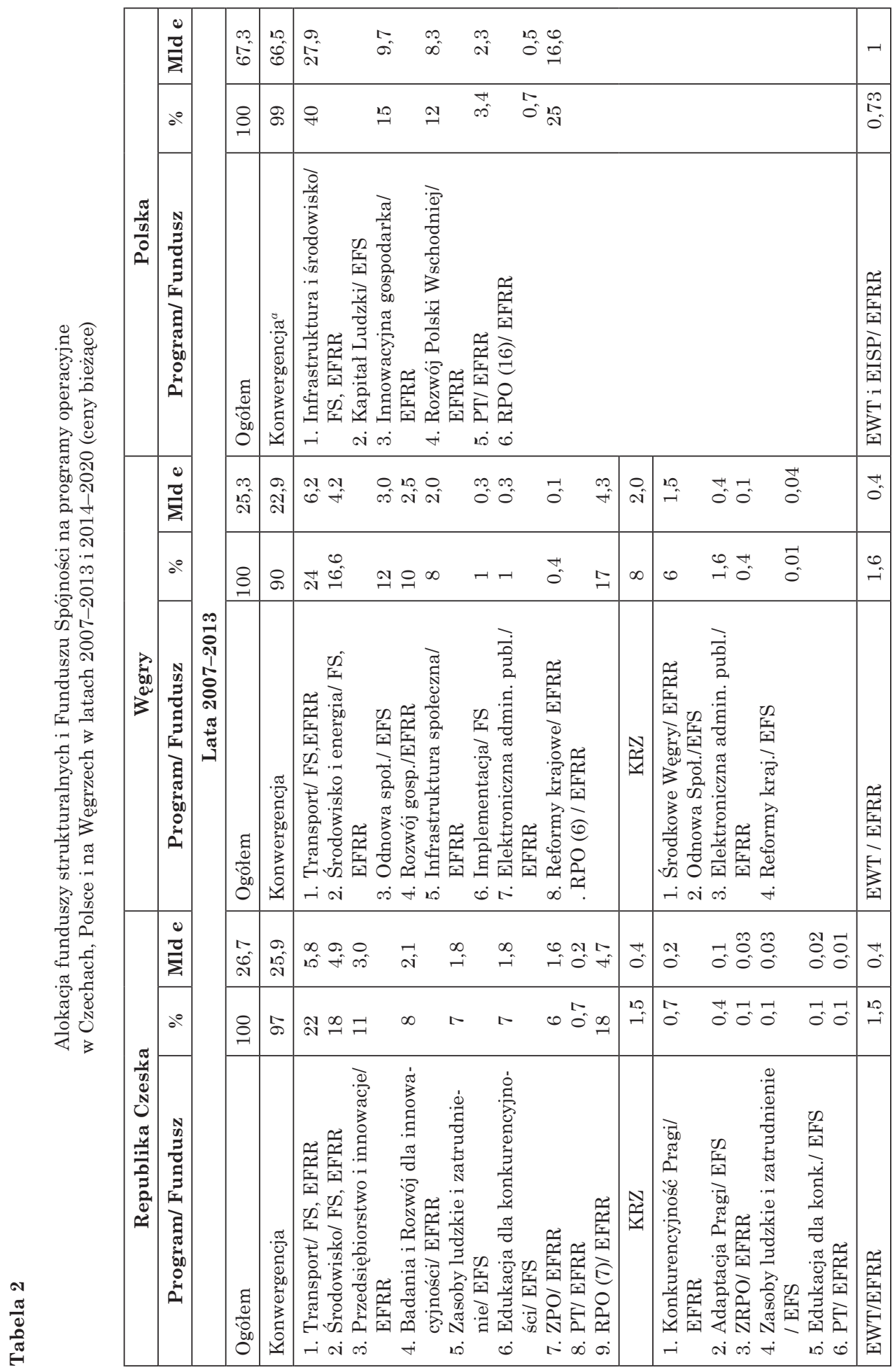




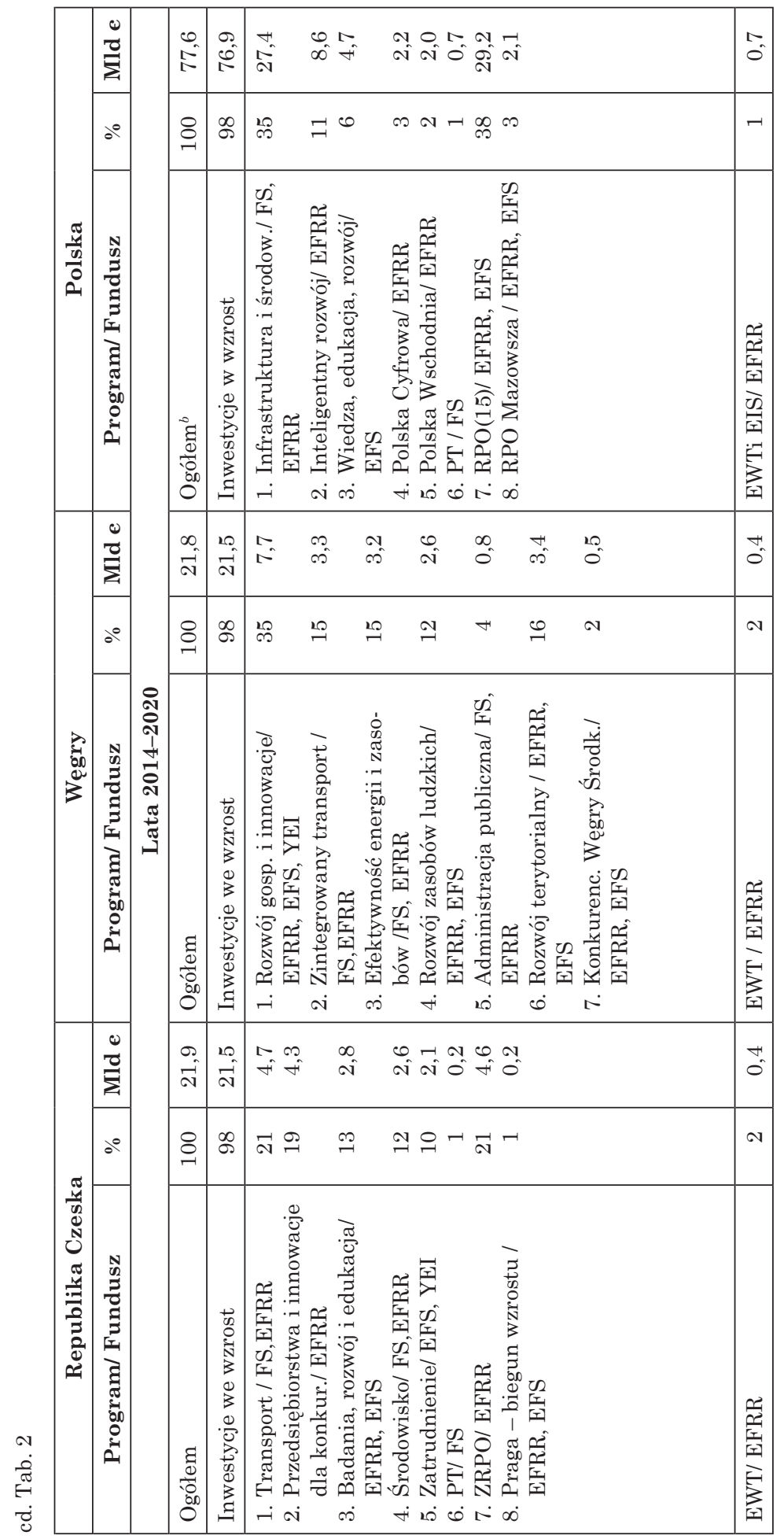

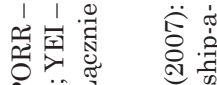

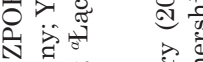

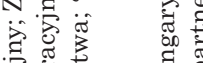

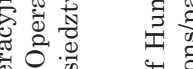

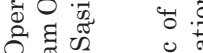

घ

कू० है द्व

至融

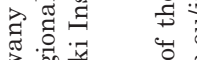

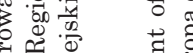

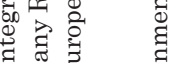

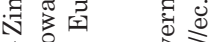

$\begin{array}{lll}1 & 1 \\ 0 & 0 & 0 \\ 0 & 0 & 0 \\ 0 & 0\end{array}$

첫

बै 1 का

ชั

范范

శึ

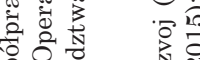

है

उत्य

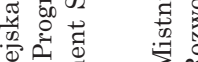

त $\Sigma$

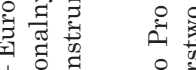

1.

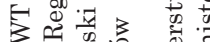

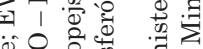

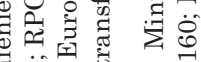

శี

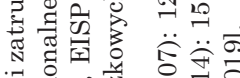

ส

䒕.

过

U.

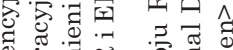

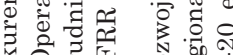

ปี

ส

N

द्व 20

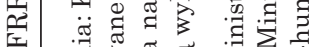

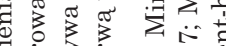

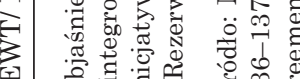


na Węgrzech i w RC. Funkcje IZ dla wspólnego programu regionalnego pełnia ich ministerstwa rozwoju regionalnego. Pogłębianie centralizacji na Węgrzech wiąże się z reformą konstytucyjną z 2011 r. i nadmiernym upolitycznieniem polityki regionalnej realizowanej przez rząd, który kontroluje tworzenie programów i selekcję projektów ${ }^{14}$. Tradycyjnie silniejsze węgierskie komitaty sa jednostkami administracji rządowej i przejęły kompetencje w zakresie wydatkowania unijnych funduszy. Słabość instytucji regionalnych i duże rozdrobnienie jednostek lokalnych w RC utrudnia ich koordynację i współpracę.

\section{WPLYW FUNDUSZY POLITYKI SPÓJNOŚCI UE NA ZRÓŻNICOWANIA REGIONALNE W POLSCE, REPUBLICE CZESKIEJ I NA WĘGRZECH}

Polityka spójności i jej fundusze są ważnym filarem wspierającym procesy wzrostu i rozwoju społeczno-gospodarczego w państwach Europy Środkowo-Wschodniej i ich regionach. Jednakże ocena ich wpływu na niwelowanie dysproporcji w poziomie rozwoju regionów nie jest jednoznaczna. Konwergencja stanowi efekt końcowy polityk w postaci zmniejszania dysproporcji społeczno-gospodarczych między regionami i krajami oraz zbieżności ich gospodarek, przeciwnie ich rozbieżność (dywergencja) jest utożsamiana ze wzrostem dysproporcji ${ }^{15}$. Na gruncie teorii i empirii wyróżniono różne typy konwergencji, kryteria ich identyfikacji i sposoby weryfikacji ${ }^{16}$. Ocena zbieżności gospodarczej opiera się na zależności między stopą wzrostu dochodu per capita a początkowym jego poziomem (konwergencja B). W jej wariancie bezwzględnym kraje i regiony upodabniają się do siebie niezależnie od warunków początkowych. Stąd regiony biedne rozwijają się szybciej niż bogate, a wzrost ich realnego PKB per capita będzie tym większy, im niższy jest jego początkowy poziom. Jest to wynikiem wyższego zwrotu z zainwestowanego tam kapitału ${ }^{17}$. Z kolei konwergencja warunkowa zakłada, że upodabniaja się do siebie kraje i regiony o podobnych czynnikach strukturalnych (np. demograficznych, poziomu wykształcenia, struktury dochodu, technologii). Konwergencja $B$ jest konieczna, nie wystarcza jednak do wystapienia konwergencji typu o. Ta ostatnia zachodzi, gdy dyspersja dochodu per capita między krajami i regionami zmniejsza się w czasie. Zgodnie zaś z koncepcją konwergencji klubów zbliżają się do siebie jedynie kraje i regiony o podobnych charakterystykach strukturalnych oraz początkowym poziomie PKB na mieszkańca, co skutkuje polaryzacją dochodu ${ }^{18}$. Liczne badania potwierdzaja pozytywny wpływ funduszy UE jako jednego z czynników przyspieszenia wzrostu gospodarek NPC, zwłaszcza

14 Loewen (2018): 260.

15 Leonardii (1995): 34.

16 Przegląd literatury zawierają m.in. Barro, Sala-i-Martin (2003); Gawlikowska-Hueckel (2003); Manfort (2008).

17 Pastuszka (2012): 262.

18 Artelaris, Kallioras, Petrakos (2010): 120. 
po rozszerzeniu ${ }^{19}$. Kompensowały one krajom peryferyjnym i słabiej rozwiniętym skutki integracji i liberalizacji handlu, umożliwiając rozwój infrastruktury, przedsiębiorstw czy kapitału ludzkiego, co sprzyjało konwergencji w UE. Raporty kohezyjne KE dowodzą zmniejszenia zróżnicowań w PKB na mieszkańca we wszystkich NPC i ich regionach w relacji do średniej UE, w szczególności przed kryzysem, jednakże największy wzrost tego miernika nastapił $\mathrm{w}$ regionach stołecznych ${ }^{20}$. Środki pomocowe ukierunkowane na inwestycje ograniczały także w pewnym stopniu wpływ kryzysu ${ }^{21}$. Natomiast w latach 2015-2017 udział środków polityki spójności w inwestycjach publicznych szacuje się na ok. $60 \%$ w Polsce, $55 \%$ na Węgrzech oraz $40 \%$ w $\mathrm{RC}^{22}$. Oficjalne raporty KE bazuja jednak na porównaniach ze średnią UE i nie odzwierciedlają dysproporcji wewnątrz państw członkowskich oraz faktycznej sytuacji w bardzo zróżnicowanych regionach.

Polska, Czechy i w mniejszym stopniu Węgry nadrabiają dystans w poziomie rozwoju gospodarczego dzielący je od UE, co odzwierciedlają dane z tabeli 3 i wzrost ich PKB per capita (według parytetu siły nabywczej) w stosunku do średniej UE-28, odpowiednio, o 19,3 punktu procentowego, 13,8 punktu procentowego i 4 punkty procentowe. Wzrost dochodu regionalnego per capita w stosunku do średniej UE odnotowały wszystkie regiony NUTS 2 w Polsce i Czechach oraz niemal wszystkie na Węgrzech (poza Południowym Zadunajem), jednak jest on najszybszy w regionach stołecznych i wysoko zurbanizowanych. Pomijając regiony stołeczne, stosunek wytworzonego PKB per capita w drugim i ostatnim pod względem tego wskaźnika regionie NUTS 2 ukazuje pewne zmiany $\mathrm{w}$ ich hierarchii oraz wzrost zróżnicowań międzyregionalnych w Czechach (z 1,16 w 2004 do 1,32 w 2017 r.) i na Węgrzech (z 1,59 do 1,65$)$ oraz podobny ich poziom w Polsce $(1,62-1,60)$. Zwiększanie dysproporcji $\mathrm{w}$ regionalnym PKB per capita potwierdza wzrost $\mathrm{w}$ badanych latach współczynnika zmienności: w Czechach z 40\% do 42\%, w Polsce z 21\% do 25\% (bez wyodrębniania z Mazowsza stołecznego regionu warszawskiego i do 36\% po jego wydzieleniu) oraz na Węgrzech podobna wartość współczynnika 35\% i 34\% przy poprzedniej klasyfikacji NUTS 2 i znaczący jego wzrost do $47 \%$ po wydzieleniu Budapesztu ${ }^{23}$. Mimo odnotowanej konwergencji krajowej na szczeblu regionalnym rozwój gospodarczy został spolaryzowany przez stolice. W efekcie można mówić o powstaniu regionalnych klubów konwergencji, z widoczna przewagą regionów metropolitalnych, zwłaszcza stołecznych. U podłoża tych różnic leży tempo zmian strukturalnych i umiędzynarodowienie firm i instytucji, posiadanie wykwalifikowanej kadry, usług dla biznesu, centrów innowacji i dostępność transportowa (sprzyja temu położenie Pragi względem

19 Matkowski, Próchniak, Rapacki (2013): 63-98.

${ }^{20}$ Komisja Europejska (2017): 3-5.

${ }^{21} \mathrm{~W}$ okresie kryzysu i restrykcyjnej polityki fiskalnej oraz malejących przychodów finansów publicznych unijne fundusze mogły nawet zastapić wydatki własne. <https://dotaceeu.cz/Dotace/ media/SF/NOK/Evaluace/Evalua\%C4\%8Dn\%C3\%AD\%20knihovna/2017/Adicionalita/Verejne-vydaje-a-fondy-EU-final-public_1.pdf> [dostęp: 20.02.2019].

${ }^{22}$ Komisja Europejska (2017): xxii-xxiii.

${ }^{23}$ Obliczenia na podstawie danych Eurostatu. 


\begin{tabular}{|c|c|c|c|c|c|c|c|}
\hline \multirow{15}{*}{ 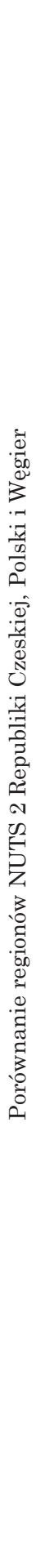 } & \multirow{6}{*}{ 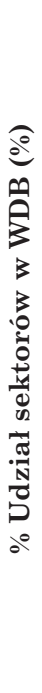 } & \multirow{2}{*}{$\frac{\sqrt{60}}{2}$} & 命 & $\stackrel{+}{+}$ & 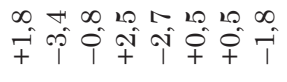 & $\stackrel{1}{\sim}$ & 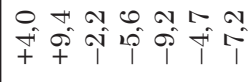 \\
\hline & & & ঙ্ণ & $\overbrace{10}^{\infty}$ & 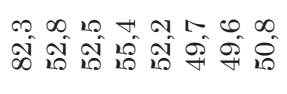 & $\begin{array}{l}N \\
10 \\
6\end{array}$ & 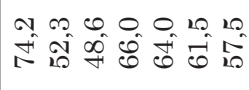 \\
\hline & & \multirow{2}{*}{ 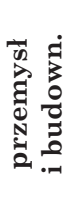 } & ำ & $\begin{array}{l}+4 \\
+\end{array}$ & 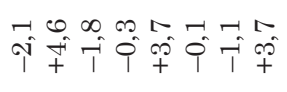 & $\begin{array}{l}\infty \\
0 \\
+\end{array}$ & 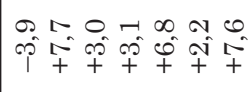 \\
\hline & & & 苍 & $\stackrel{n}{\infty}$ & 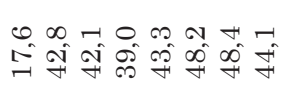 & 悳 & 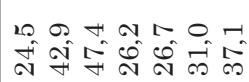 \\
\hline & & \multirow{2}{*}{ ఏ } & 点 & $\stackrel{\infty}{\infty}$ & 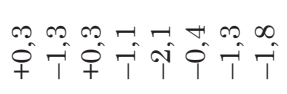 & $\begin{array}{l}10 \\
0 \\
+\end{array}$ & 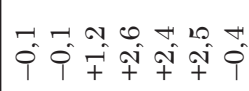 \\
\hline & & & ஓ্ণ & $\stackrel{\infty}{\infty}$ & 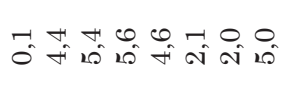 & $\begin{array}{l}0 \\
\infty\end{array}$ & 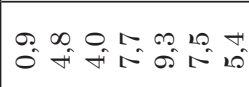 \\
\hline & \multirow{3}{*}{\multicolumn{2}{|c|}{ 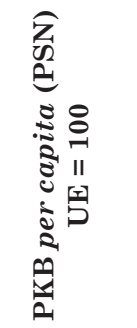 }} & 첨 & $\begin{array}{l}\infty \\
\infty \\
+\end{array}$ & 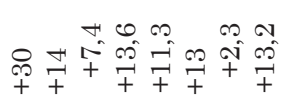 & $\stackrel{4}{+}$ & 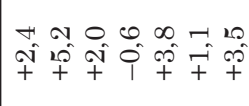 \\
\hline & & & 궁 & $\stackrel{\infty}{\infty}$ & 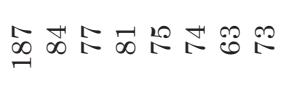 & $\begin{array}{l}\infty \\
0\end{array}$ & 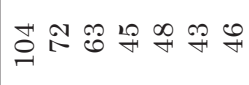 \\
\hline & & & ஓ্ণ & 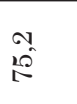 & 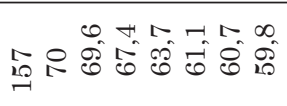 & $\frac{0}{60}$ & 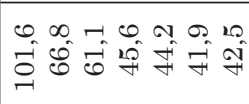 \\
\hline & \multirow{2}{*}{\multicolumn{2}{|c|}{ 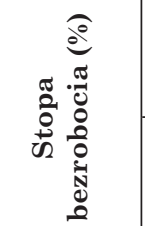 }} & 동 & बे & 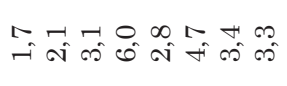 & $\stackrel{N}{f}$ & 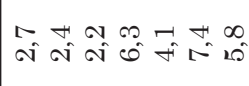 \\
\hline & & & 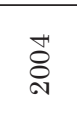 & $\stackrel{\infty}{\infty}$ & 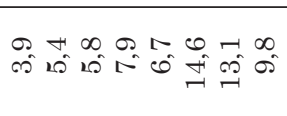 & - & 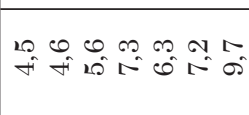 \\
\hline & \multirow{2}{*}{\multicolumn{2}{|c|}{ 苋 }} & 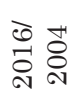 & $\stackrel{10}{+}$ & 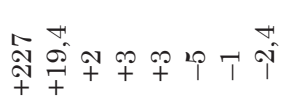 & $\stackrel{4}{H}$ & 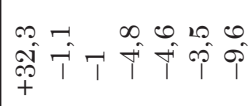 \\
\hline & & & 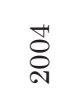 & ๙ื & ஓి & $\underset{-1}{2}$ & 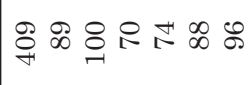 \\
\hline & \multicolumn{3}{|c|}{ 完 } & $\stackrel{\infty}{\infty}$ & 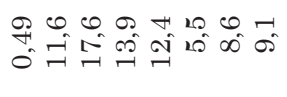 & مी & 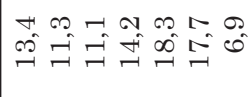 \\
\hline & \multicolumn{3}{|c|}{ 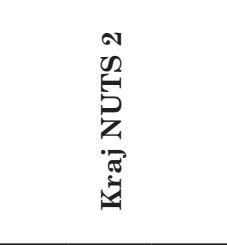 } & 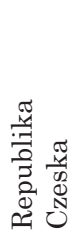 & 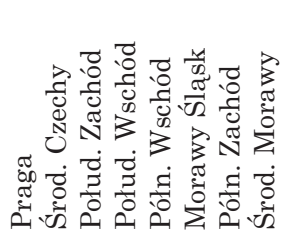 & $\sum_{\infty}^{\infty}$ & 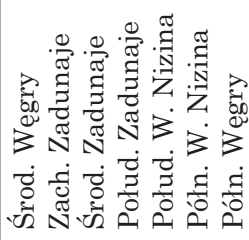 \\
\hline
\end{tabular}




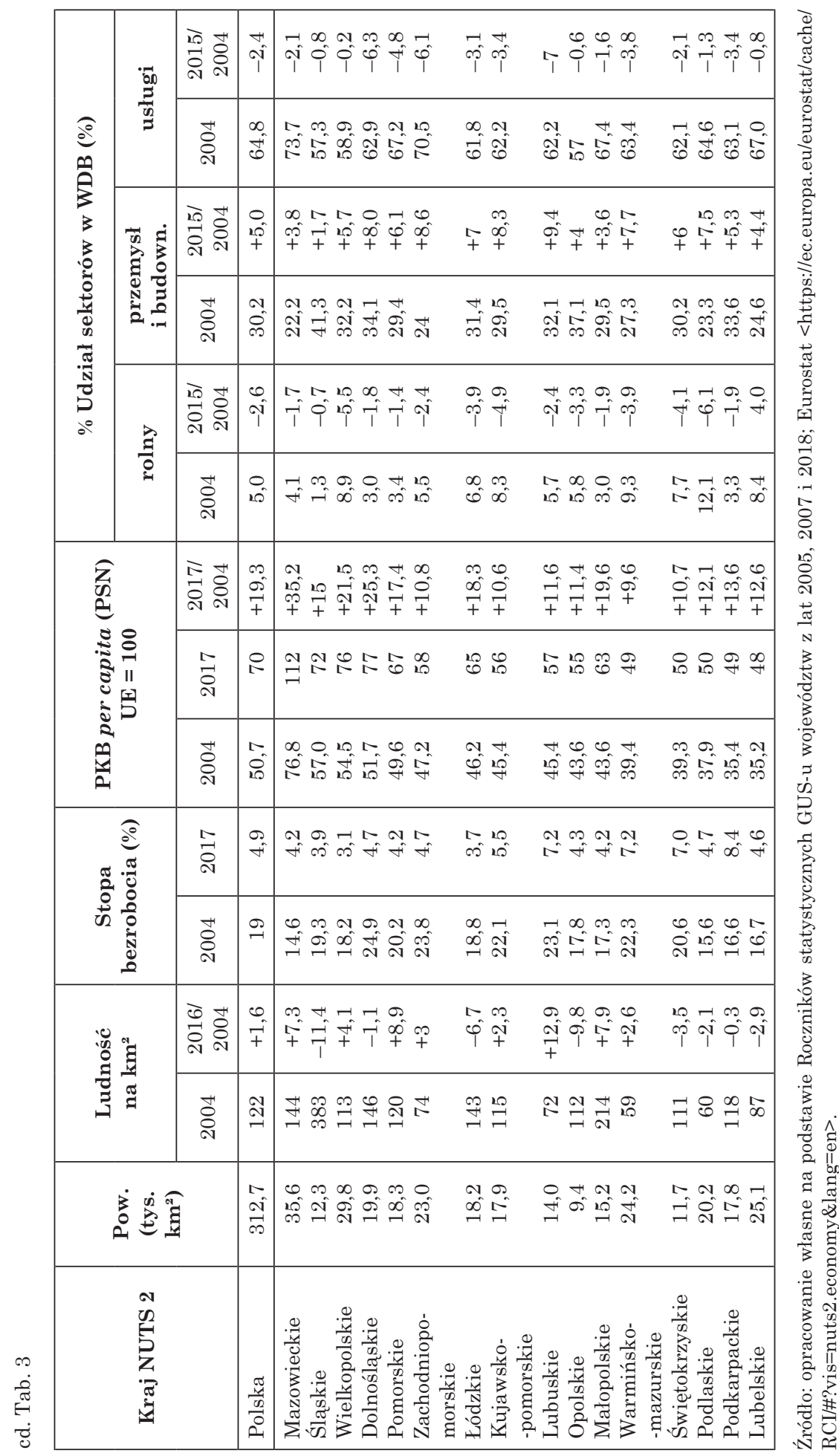


rynków zachodnich oraz centralne położenie Budapesztu). Procesy globalizacji i metropolizacji napędzaja dalszy ich wzrost gospodarczy, co skutkuje narastaniem dysproporcji regionalnych. Nakładają się one na tradycyjne podziały horyzontalne (zachód-wschód), które wynikały z tempa restrukturyzacji przemysłu, bliskości rozwiniętych rynków i relacji z sąsiednimi landami niemieckimi (Czechy, Polska) czy austriackimi (Węgry) oraz dostępności transportowej (rozwinięta infrastruktura), co sprzyjało napływowi inwestycji zagranicznych. Jednakże nie wszystkie regiony wykorzystuja rentę położenia, w efekcie dynamika ich wzrostu słabnie (np. województwa zachodniopomorskie i lubuskie czy północno-zachodnie Czechy). W szczególnie niekorzystnej sytuacji znajdują się tereny rolnicze, usytuowane zwłaszcza na granicach państwa, a nawet wybiegające w obszar sasiedniego państwa (jak czeskie cyple) oraz o trudnych warunkach geograficznych (pogranicze węgiersko-rumuńskie wzdłuż Dunaju) ${ }^{24}$. Ukazane w tabeli 3 zmiany w strukturze gospodarek regionów słabiej rozwiniętych: spadek udziału rolnictwa i wzrost produkcji przemysłowej w WDB oraz przyspieszenie rozwoju w relacji do średniej UE, rodzą ostrożny optymizm. Rozkład terytorialny i kierunki wydatkowania unijnych funduszy mogą utrwalać regionalne zróżnicowania rozwoju. W konkurencji o główną pulę unijnych środków na programy krajowe przewagę miały największe miasta i silniejsze regiony, gdzie zlokalizowani sa główni ich beneficjenci, łatwiej sprostały one wymogom dużych projektów i wkładu własnego. Po dwóch okresach programowania w RC największe publiczne środki unijne i krajowe otrzymały na poziomie NUTS 3: Karlowe Wary (Północny Zachód) i pilzneński kraj (Południowy Zachód), odnotowujące najniższy wzrost $\mathrm{PKB}^{25}$. Większe wsparcie trafiło także do Środkowych Czech, regionu z drugim najwyższym PKB per capita, podczas gdy najmniejsze fundusze per capita, poza Praga, otrzymał biedniejszy Północny Wchód (kraj Kralovehradecki). Podobnie na Węgrzech, Zachodnie Zadunaje otrzymało większe wsparcie niż biedniejsze Środkowe Zadunaje, a Południowa i Północna Wielka Nizina w porównaniu z Północnymi Węrami ${ }^{26}$. W latach 2004-2006 niemal połowę unijnych funduszy trafiło do najbogatszych i najludniejszych województw: mazowieckiego, ślasskiego, dolnoślaskiego i wielkopolskiego, podczas gdy udział pięciu najbiedniejszych województw z Polski wschodniej wyniósł niespełna $15 \%{ }^{27}$. Ich udział w funduszach strukturalnych wzrósł dzięki większej puli środków w ramach RPO, PO Rozwój Polski Wschodniej (łącznie 28\% w latach 2007-2013) oraz komponentu regionalnego PO Kapitał Ludzki. W latach 2014-2020 udział 15 RPO i PO Polska Wschodnia wyniósł 40,5\%. Dodatkowym wsparciem obszarów wiejskich był Program Rozwoju Obszarów Wiejskich (dofinansowany z EFRROW). Z funduszy polityki spójności więcej środków per capita trafiło w tych województwach do miast, głównie ich stolic (przede wszystkim na

\footnotetext{
${ }^{24}$ Smętkowski, Wójcik (2012): 936-937.

25 Hrůza, Volčik, Žaček (2019): 81-82.

26 Horrige, Rokicki (2018): 513.

27 Ministerstwo Rozwoju Regionalnego (2010): 33-34.
} 
inwestycje transportowe, wsparcie konkurencyjności i innowacyjności czy infrastrukturę społeczna) aniżeli na obszary wiejskie i miejsko-wiejskie (gdzie dominowały infrastruktura transportu, ochrona środowiska i energetyka) ${ }^{28}$. Skierowanie unijnych funduszy na inwestycje w podstawową infrastrukturę wywołuje głównie efekty popytowe, wzrost zatrudnienia i konsumpcji. Natomiast długookresowy wzrost, zmiany strukturalne i poprawa konkurencyjności mogą natrafić na bariery podażowe i demograficzne.

\section{WNIOSKI}

Po akcesji do UE w państwach Europy Środkowo-Wschodniej następuja recentralizacja systemów instytucjonalnych i renacjonalizacja programów wdrażanych w ramach polityki regionalnej (spójności), szczególnie widoczne na Węgrzech, ale także w Czechach i w mniejszym stopniu w Polsce ${ }^{29}$.

Wzrost ich udziału w budżecie polityki spójności na lata 2007-2013 przełożył się na wzrost finansowania regionów, przez odrębne regionalne programy operacyjne regionów NUTS 2 (zgodnie z ich zakwalifikowaniem do celów) i rozszerzenie kompetencji instytucji regionalnych (poza Węrami). Zmniejszenie puli unijnych środków dla Czech i Węgier prowadzi do centralizacji zarządzania nimi. W każdym okresie preferowane sa programy krajowe (sektorowe), w efekcie na programy regionalne przypadło w latach 2007-2013 od 20\% alokacji na Węgrzech do 28\% w Polsce. W latach 2014-2020 w Czechach i na Węgrzech własne programy maja jedynie Praga i Środkowe Węgry (regiony lepiej rozwinięte), pozostałe zaś regiony (słabiej rozwinięte) maja jeden wspólny program operacyjny zarządzany przez ministerstwo. Efektem było zmniejszenie ich udziału w unijnych środkach do $17,6 \%$ (15,5\% na regiony słabiej rozwinięte) na Węgrzech oraz do $22 \%$ (21\% regiony słabiej rozwinięte) w Czechach. W Polsce kontynuacja 16 RPO i programu Polska Wschodnia wiąże się ze wzrostem udziału województw w alokacji funduszy strukturalnych do 43\% (w tym 40,5\% dla regionów słabiej rozwiniętych). Zmniejszenie po 2020 r. budżetu polityki spójności i jej funduszy, intensywności pomocy oraz propozycje powiązania jej - poza relatywnym PKB per capita - z dodatkowymi wskaźnikami oznaczają istotne zmniejszenie wsparcia dla Polski, Czech i Węgier o $23 \%-24 \%$ w porównaniu z okresem bieżącym ${ }^{30}$. Koncentracja na 5 celach tematycznych pozwala przewidywać podobną liczbę programów sektorowych i wzrost nakładów na innowacje, cyfryzację, energetykę i środowisko, jeden program regionalny lub programy odpowiadajace zakwalifikowaniu do odpowiedniej kategorii regionów w Czechach i na Węgrzech oraz kontynuację 16 RPO w Polsce.

\footnotetext{
28 Ministerstwo Inwestycji i Rozwoju \& Imapp (2017): 19.

29 Bruszt (2008): 607-627.

${ }^{30}$ W cenach z 2018 r. Bachtler, Mendez, Wishlade (2018): 43.
} 
Regiony stołeczne pozostaną w kategorii lepiej rozwiniętych (powyżej 100\% średniej UE-27 za lata 2014-2016), natomiast województwo dolnośląskie oraz Środkowe Czechy, Południowy Wschód i Zachód awansują do regionów przejściowych (75\%-100\% średniej UE-27). Tym samym będą konkurować o fundusze unijne $\mathrm{z}$ silniejszymi gospodarczo regionami starych państw członkowskich ${ }^{31}$.

Programy regionalne i lokalne zapewniają lepsze dopasowanie wsparcia do potrzeb i specyfiki zróżnicowanych regionów. Natomiast słaba reprezentacja ich interesów i udział w zarządzaniu funduszami UE wiąże się z brakiem oparcia regionów NUTS $2 \mathrm{w}$ administracji publicznej (na Węgrzech i w Czechach) i samodzielności finansowej, a także z upolitycznieniem funduszy unijnych przez rządy krajowe i KE. „Lizbonizacja” polityki spójności, kontynuowana w jej celach na lata 2014-2020 i 2021-2027, oznacza odejście od modelu wyrównawczego i wzmacnia pozycję największych miast i innowacyjnych regionów. Ponadto skupianie się jedynie na zbieżności gospodarczej nie uwzględnia między innymi zmian w środowisku i demografii, dobrobytu społecznego (konwergencja wielowymiarowa). Efektem negatywnych trendów demograficznych jest wyludnianie się obserwowane zarówno w regionach gospodarczo słabszych, jak i silniejszych (np. województwa śląskie i łódzkie, wszystkie regiony węgierskie poza stołecznym).

Joanna Szafran

Uniwersytet Marii Curie-Sktodowskiej w Lublinie

joanna.szafran@poczta.umcs.lublin.pl

https://orcid.org/0000-0002-8814-5401

Artelaris, P., Kallioras, D., Petrakos, G. (2010). Regional inequalities and convergence clubs in the European Union new member-states. Eastern Journal of European Studies 1: 113-133.

Bachtler, J., Downes, R., Gorzelak, G. (eds.) (2000). Transition, Cohesion and Regional Policy in Central and Eastern Europe. Ashgate. London.

Bachtler, J., Mendez, C., Wishlade F. (2018). Proposals for the MFF and Cohesion Policy 20212027: A Preliminary Assessment. EPRC. University of Strathclyde. Glasgow.

Barro, R.J., Sala-i-Martin, X. (2003). Economic Growth. Cambridge-London: The MIT Press.

Bruszt, L. (2008). Multi-level governance - the Eastern versions: emerging patterns of regional developmental governance in the new member states. Regional and Federal Studies 18: $607-627$.

Domański, B., Guzik, R., Micek, G. (2003). Zróżnicowania regionalne krajów Europy Środkowo-Wschodniej i jego zmiany w latach 1995-2000. Biuletyn KPZK PAN 204: 125-142.

Dorożyński, T. (2012). Rola polityki spójności Unii Europejskiej w usuwaniu regionalnych nierówności gospodarczych. Wnioski dla Polski. Łódź: Wydawnictwo Uniwersytetu Łódzkiego.

Gawlikowska-Hueckel, K. (2003). Procesy rozwoju regionalnego w Unii Europejskiej. Konwergencja czy polaryzacja. Gdańsk: Wydawnictwo Uniwersytetu Gdańskiego.

The Government of the Republic of Hungary (2007): The New Hungary Development Plan. National Strategic Reference Framework of Hungary 2007-2013. Employment and Growth.

${ }^{31} \mathrm{~W}$ nowej perspektywie populacja objęta kategoria przejściową wzrośnie niemal dwukrotnie, a w regionach lepiej rozwiniętych o $1 / 3$, co doprowadzi w nich do spadku wsparcia per capita odpowiednio o 20,7\% i 10\%. Bachtler, Mendez, Wishlade (2018): 30-31. 
Horridge, M., Rokicki, B. (2018). The impact of European Union accession on regional income convergence within the Visegrad countries. Regional Studies 52(4): 503-515.

Hrůza, F., Volčik, S., Žaček, J. (2019). The impact of EU Funds on regional economic growth of the Czech Republic. Czech Journal of Economics and Finance 69(1): 80-82.

Klimowicz, M. (2014). Ewolucja celów polityki regionalnej Unii Europejskiej w procesie integracji gospodarczej, [w:] A. Pacześniak, M., Klimowicz (red.), Procesy integracyjne i dezintegracyjne w Europie. Wrocław: OTO - Wrocław: 203-236.

Komisja Europejska (2017). Mój region, moja Europa, nasza przyszłość. Siódmy raport na temat spójności gospodarczej, społecznej i terytorialnej. Luksemburg: Urząd Publikacji UE.

Leonardi, R. (1995). Convergence, Cohesion and Integration in the European Union. London: Palgrave Mcamillan.

Loewen, B. (2018). Cohesion Policy and institutional change in Hungary and Estonia. Regional Studies, Regional Science 5(1): 255-262.

Manfort, P. (2008). Convergence of EU regions measures and evolution. Working Paper No. 1, European Union Regional Policy, European Commission.

Matkowski, Z., Próchniak, M., Rapacki, R. (2013). Nowe i stare kraje Unii Europejskiej: konwergencja czy dywergencja? Prace i Materiały Instytutu Rozwoju Gospodarczego SGH 91: 63-98.

Ministerstwo Gospodarki, Pracy i Polityki Społecznej (2003). Podstawy Wsparcia Wspólnoty. Promowanie rozwoju gospodarczego i warunków sprzyjających wzrostowi zatrudnienia. Warszawa.

Ministerstwo Infrastruktury i Rozwoju (2017). Programowanie perspektywy 2014-2020. Umowa Partnerstwa. Warszawa.

Ministerstvo Pro Mistni Rozvoj (2007). National Strategic Reference Framework of the Czech Republic 2007-2013.

Ministerstvo Pro Mistni Rozvoj (2003): Rámec Podpory Společenstvi Česka Republika 2004-2006. CCI: 2003C161CC001.

Ministerstwo Rozwoju Regionalnego (2007). Narodowe Strategiczne Ramy Odniesienia 2007-2013 wspierające wzrost gospodarczy i zatrudnienie. Narodowa Strategia Spójności. Warszawa.

National Development Office (2003). Community Support Framework 2004-2006. Republic of Hungary, Objective 1 of the Structural Funds. CCI: 2003 HU 161 CC 001.

Pálmai, Z. (2013). 2007-2013: Hungarian multi-level governance with or wihout regions? [w:] I.P. Kovács, J. Scott, Z. Gál (eds.), Territorial Cohesion in Europe. Pécs: Hungarian Academy of Sciences: 455-466.

Pastuszka, S. (2012). Polityka regionalna Unii Europejskiej - cele, narzędzia, efekty. Warszawa: Difin.

Pietrzyk, I. (2001). Polityka regionalna Unii Europejskiej i regiony w państwach członkowskich. Warszawa: Wydawnictwo Naukowe PWN.

Smętkowski, M., Wójcik, P. (2012). Regional convergence in Central and Eastern European Countries: a multidimensional approach. European Planning Studies 20(6): 923-939.

Szafran, J. (2016). Wdrażanie polityki spójności Unii Europejskiej w Republice Czeskiej w perspektywie programowania 2014-2020. Barometr Regionalny. Analizy i Prognozy 14: 95-101.

Świstak, M. (2018). Polityka regionalna UE jako polityka publiczna. Wobec potrzeby optymalizacji publicznego działania. Kraków: Wydawnictwo Uniwersytetu Jagiellońskiego.

\section{PROGRAMMING AND IMPLEMENTING STRUCTURAL FUNDS AND THE COHESION FUND IN POLAND, THE CZECH REPUBLIC AND HUNGARY: EFFECTS AND PROSPECTS}

Summary

Poland, the Czech Republic and Hungary are the largest beneficiaries among the countries of the so-called great accession. They showed a number of geopolitical and historical similarities, a lower level of development in relation to the EU15, and growing regional disparities. The aim of the article is to assess the effectiveness of implementing cohesion policy funds in these countries with regard to bridging the development gap and disparities between regions. The scope 
of the analysis covers the programming and management systems of the Structural Funds and the Cohesion Fund in these countries in the periods: 2004-2006, 2007-2013, 2014-2020 and the post-2020 perspective. Changes in the allocation priorities of the EU funds are associated with the centralization of their management systems (especially in Hungary). Limited effects in regional convergence indicate that the main beneficiaries of the cohesion policy are the dynamically developing capital and metropolitan regions, not the least developed ones. Poor representation of the regions' interests results from a lack of strong public administration and limited financial independence. The basis of the analysis are the programming documents, literature research, and data from Eurostat and the statistical offices of these countries.

Keywords: Structural Funds; Cohesion Fund; programming and implementation of EU Funds; regional disparities 
